\title{
Development of a Japanese version of the Pain Disability Index: translation and linguistic validation
}

\author{
Keiko Yamada ${ }^{1,2,3}$, Akira Mibu ${ }^{4,5}$, Sonora Kogo ${ }^{6}$, \\ Masako Iseki ${ }^{3}$, and Tomohiko Nishigami ${ }^{7}$ \\ ${ }^{1}$ Department of Psychology, McGill University, Montreal, Quebec, Canada \\ ${ }^{2}$ Japan Society for the Promotion of Science \\ ${ }^{3}$ Department of Anesthesiology and Pain Medicine, Juntendo University Faculty of Medicine \\ ${ }^{4}$ Department of Nursing and Physical Therapy, Konan Women's University \\ ${ }^{5}$ Department of Rehabilitation, Tanabe Orthopedics \\ ${ }^{6}$ Department of Psychology, Concordia University, Montreal, Quebec, Canada \\ ${ }^{7}$ Department of Physical Therapy, Prefectural University of Hiroshima
}

\begin{abstract}
The Pain Disability Index (PDI) is a self-reported outcome measure initially developed in English to assess disability caused by pain in seven dimensions of daily life activity, including family/home responsibilities, recreation, social activity, occupation, sexual behavior, self-care, and life-support activity. This study aimed to develop a linguistically valid Japanese version of the PDI (PDI-J) according to the guidelines for the translation and cultural adaptation of patient-reported outcome measures established by the task force of the International Society for Pharmacoeconomics and Outcomes Research. A draft of the PDI-J was developed through a forward translation of the original PDI from English to Japanese, reconciliation of the translation, backtranslation from Japanese to English, and harmonization. We subsequently conducted a cognitive debriefing in five patients using the PDI-J draft and reviewed it before finalizing a linguistically valid PDI-J. We also considered a five-item version of the PDI (PDI-5-J), which excluded two items (sexual behavior and life-support activity) from the original version. This consideration was made for brevity and because sexual behavior is a considerably personal parameter that some patients may be reluctant to answer and life-support activity because it was considered ambiguous in Japanese. Therefore, we were able to develop a linguistically valid PDI-J and PDI-5-J through this process. Further study is warranted to confirm the psychometric validity and reliability of the two indices (PDI-J and PDI-5-J).
\end{abstract}

Keywords

Pain; Disability evaluation; Surveys and questionnaires;

Translating outcome measures; Pain Disability Index 


\title{
日本語版疼痛障害指標 Pain Disability Index (PDI) の開発 : 言語的妥当性を担保した翻訳版の作成
}

\author{
山田 恵子 $1,2,3$ /壬生 彰 4,5 /向後響 $6 /$ 井関 雅子 3 /西上 智彦 7 \\ 1 マギル大学 心理学科, ${ }^{2}$ 日本学術振興会, ${ }^{3}$ 順天堂大学医学部 麻醉科学・ペインクリニック講座, \\ ${ }^{4}$ 甲南女子大学 看護リハビリテーション学部 理学療法学科, ${ }^{5}$ 医療法人暁会 田辺整形外科, \\ 6 コンコルディア大学 人文科学部 心理学研究科, ${ }^{7}$ 県立広島大学 保健福祉学部 理学療法学科
}

\section{はじめに}

痛みの慢性化予防，あるいはすでに慢性化し た痛みの治療においては，痛みそのものをゼロ にすることではなく，痛みによってもたらされ る生活障害の軽滅が目標となる1)。そのため, 痛 みによってもたらされている生活障害がどの程 度かという定量的評価を行うことが大変重要で あり，日本における痛みの臨床や研究の現場で は，日本で開発された自記式質問票である疼痛 生活障害評価尺度 (Pain Disability Assessment Scale: PDAS) が普及している2)。PDAS は 20 種類の日常生活活動が痛みによってどの程度妨 げられているかを患者自身が評価するもので, 患者評価に有用な質問票であるが，項目数が 20 種類と比較的多いことから同一患者に対し て前向きに複数回害施するには負担が大きいこ とや，日本独自の尺度であるために国際比較が 困難であるという問題点があった。

今回, 痛みによる生活障害の簡便な尺度とし て国際的に普及している Pain Disability Index （PDI）を日本語に翻訳し，言語的妥当性を担保 した日本語版を作成したので報告する 3,4)。PDI は 1981 年に Dr. Alec Pollard が開発して学位
}

論文として執筆した後, Dr. Pollard 自身によっ て 1984 年にその妥当性が報告されている3)。 PDI の英語版原作は日常生活における 7 種類の 行動や活動（Family/home responsibilities, Recreation, Social activity, Occupation, Sexual behavior, Self-care, Life-support activity) に対 する痛みの影響を評価できるようデザインされ ている。

\section{対象と方法}

PDI の日本語翻訳にあたって, 英語版原作者 の Dr. Pollard は高齢で退職されていたため, Dr . Pollard が責任者を勤めていたセントルイス 大学の担当部署に問い合わせ，現在 PDI の英語 版原作の管理者に相当する Dr. Raymond Tait から日本語版翻訳の許可を取得した上で，言語 的に妥当な尺度の翻訳版を作成する際に標準的 に使用される，ISPOR (International Society for Pharmacoeconomics and Outcomes Research) タスクフォースによる尺度翻訳に関する指針 （ガイドライン）に準拠して翻訳を実施した (Fig.1) $)^{5,6)}$ 


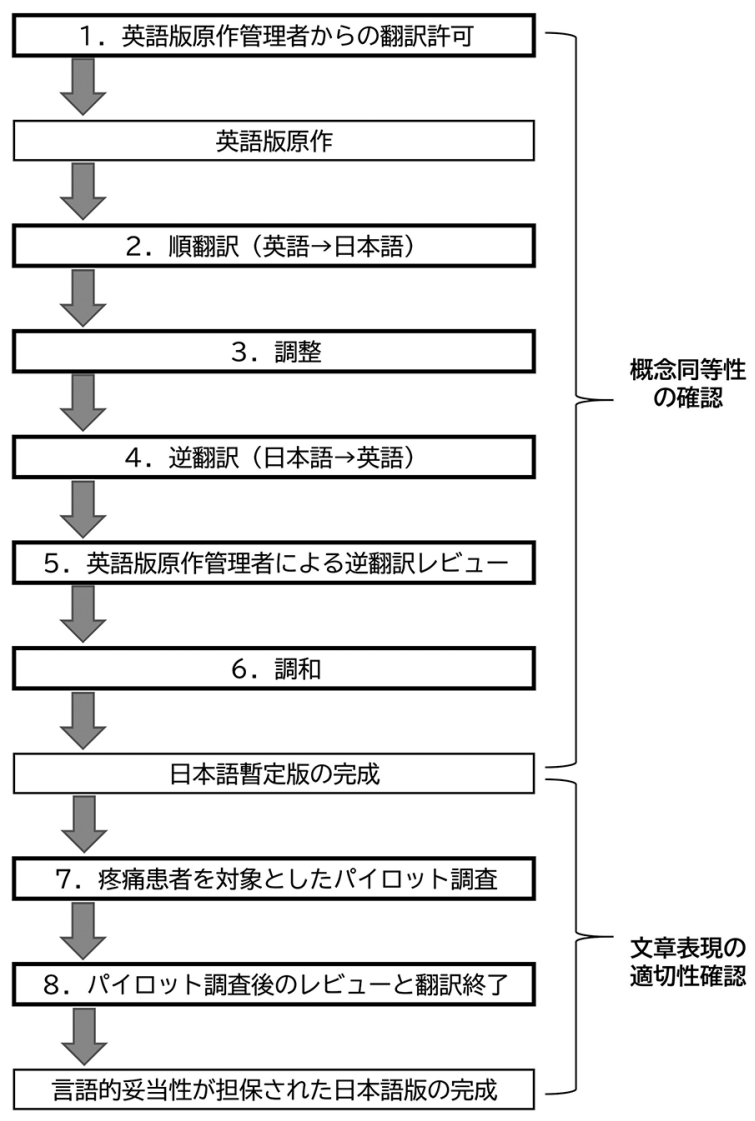

Fig.1 英語版疼痛障害指標を日本語版に翻訳する 手順について

Translation process of the English Pain Disability Index into Japanese

\section{1. 日本語暫定版の完成まで}

(Fig.1 : 手順 2 6)

翻訳は Dr. Tait の助言により, 1984 年の PDI 初版と項目内容は同一で, 説明文と選択肢 の初版運用上の問題点を改善した改訂版 PDI (1994 年発表) を元に実施した ${ }^{4)}$ 。Dr. Taitは 1994 年改訂版 PDI の妥当性や基準点を検討し た論文の共著者である ${ }^{4)}$ 。以下，この改訂版 PDI のことを「原作版」と記す。(Fig.2に PDI 各版の比較を示した。)

その後, Dr. Michael Sullivan らの研究グルー プが，PDIに含まれる7つの質問項目から “sexual behavior” と “life-support activity”を除 く 5 項目をそのまま抜粋し, 説明文の “pain”を より広範囲の健康状態である “health and mental health conditions”に広げ，疼痛だけでな く広い評価に使用可能な Disability Index を開 発した。Disability IndexはDr. Sullivan らが 実施する行動療法プログラムを用いた臨床研究 や患者評価に広く使用されている7)。Disability Index の開発経緯について Dr. Sullivanによる と, なるべく項目数を減らして簡便さを優先し たいと考えたことと, 彼らのプログラムは疼痛 以外を主訴とする患者にも実施していることか ら評価対象を広げたそうである。

今回, PDI の日本語翻訳版を作成し使用する にあたっても評価が簡便であるほど良いため, 著者らは疼痛評価専用の 5 項目版フォーマット として, Disability Index を参考に, 英語原作版 PDI の説明文のまま, PDI の 7 項目から “sexual behavior” と “life-support activity”を除いた 5 項目を抜粋した日本語翻訳版 PDI のフォー マットも併せて作成した。その理由として, 日 本でPDI を実施する際に Disability Index で除 外されている “sexual behavior” と “life-support activity”について, “sexual behavior” の評価は 重要であるが極めてプライベートな事柄である ことから答えづらく，対象年齢や宗教等によっ ては不適当な設問となりうることからデリケー 卜な項目で, かつ “life-support activity”につ いては，設問意図が分かりづらいと文化的に考 察したからである。そして, Disability Index は痛み以外の健康状態全般の評価に用いること ができるように質問文にさらなる改訂が施され ているが，筆者らは原作版 PDI と同じくあく まで疼痛による生活障害に特化した評価を行い たいと考えたため，原作版の質問文を採用した。 5 項目版も併せて作成することについても, 原 


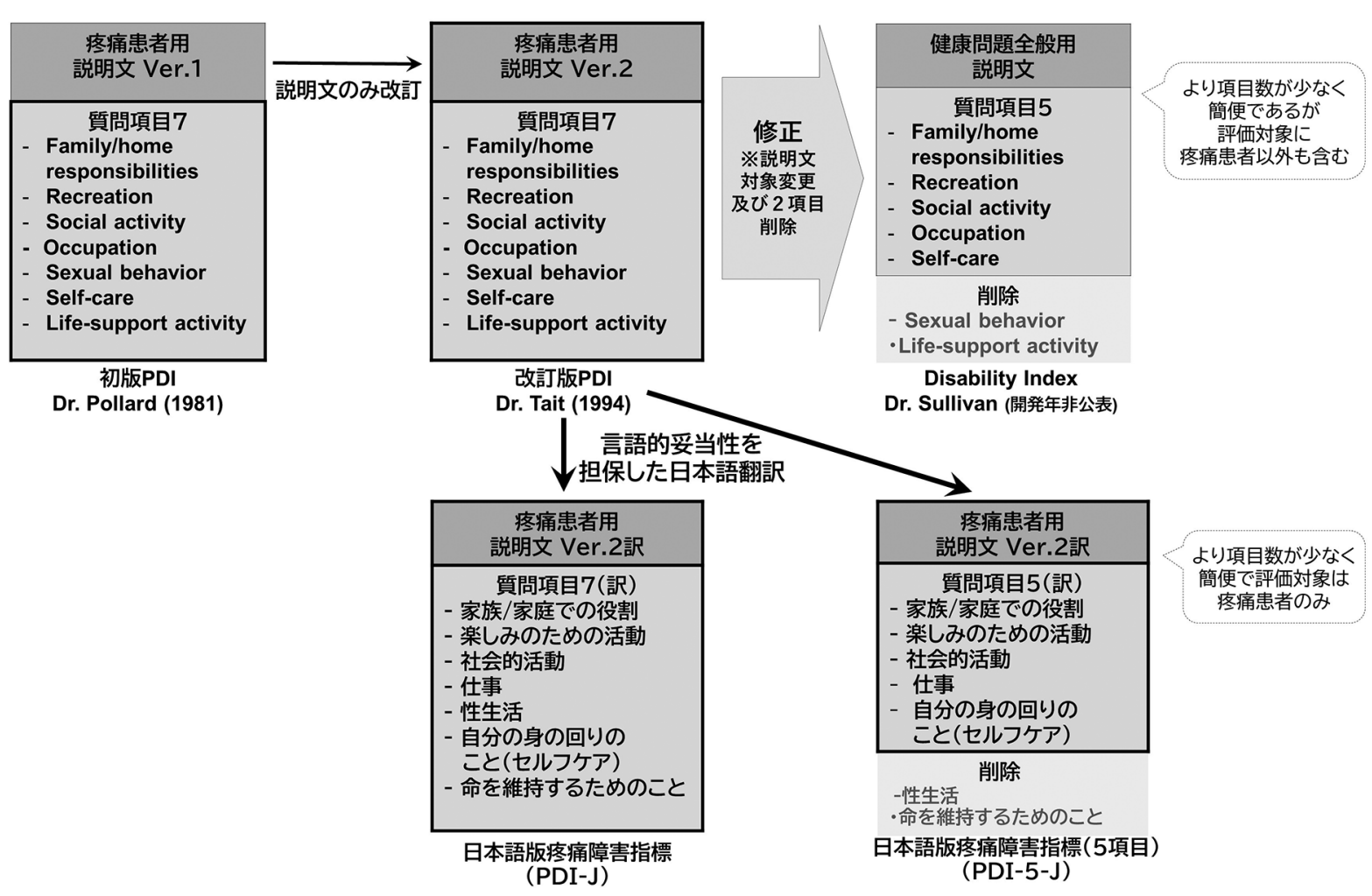

Fig.2 これまでに開発された疼痛障害指標と今回翻訳した疼痛障害指標についての整理 Various versions of the Pain Disability Index

作版管理者の Dr. Tait から承諾を得ている。

まず，日本語を母国語とする 2 名の翻訳者 （日本語を母国語とし，疼痛の臨床および研究 経験のある理学療法士 2 名）が，原作版をお互 いの訳がわからない条件下でそれぞれ順翻訳し た (手順 2)。2名の翻訳者とは別の 1 名（日本 語を母国語とし, 疼痛の臨床および研究経験の ある医師）がそれぞれの翻訳案を検討し，1つ の案にまとめた後, 上記 3 名によりオンライン 会議による協議を通して，順翻訳に対する調整 を実施した (手順 3)。

調整済みの順翻訳はカナダに居住し, 日本文 化に精通する日英仏 3 力国語話者（トリリンガ ル）により逆翻訳が実施された（手順 4)。得ら れた逆翻訳は英語版原作管理者である Dr. Tait によりレビューが実施された（手順 5)。Dr.
Taitによるレビュー内容をうけ，上記順翻訳 の調整までを実施した 3 名および逆翻訳を実施 したトリリンガル 1 名（以下，逆翻訳者と記 載）の合計 4 名でオンライン会議による協議を 実施し，Dr. Tait とは電子メール上のやりとり を用いて説明文や質問項目の作成意図や，文化 背景の違いを調整し (手順 6), 概念同等性が確 認された日本語暫定版を完成した。

\section{2. 疼痛患者を対象としたパイロット調查} (Fig.1 : 手順7)

日本語暫定版の文章表現の適切性や患者に とっての設問への回答しやすさを検討するため, 個別面談方式によるパイロット調查を，2020 年 7 月から 8 月に医療法人曉会田辺整形外科 （大阪府天王寺区）で実施した。実施にあたっ 
ては，個人情報は一切収集しないなど，調查協 力者のプライバシーには十分配慮した。また, 本調查は順天堂大学医学部研究等倫理委員会で の承認を得て実施した（承認日：2020 年 4 月 23 日, 承認番号: 順大医学倫第 2020029 号)。

パイロット調查は医療法人曉会田辺整形外科 に通院する患者のうち，体のどこかに痛みを有 し，日本語を母国語とする 5 名（女性 3 名，男 性 2 名, 平均 50.2 歳) の患者を対象に実施され た。対象者には事前に調查目的についての十分 な説明を行い，書面による調查協力についての 同意が得られた後に，日本語暫定版への回答と 回答終了後のインタビューを求めた。調查寒施 の説明，同意書の取得，自記式質問票の配布押 よびインタビューは医療法人曉会田辺整形外科 に勤務する，過去に同様のパイロット調查経験 のある理学療法士 1 名が実施した。また，パイ ロット調查の実施者は, 患者の回答時間をス トップウォッチで計測した。

回答終了後, 患者に対して, 文章表現の適切 性や患者にとっての設問への回答しやすさに関 するインタビューを実施した。インタビューの 内容は松平ら (2013) が言語的妥当性を担保し た日本語版版 Tampa Scale for Kinesiophobia （TSK-J）を開発した先行調查を参考に ${ }^{8) ，(1) ~}$ 質問票全般の印象（全体的にわかりやすいか, 回答に要する時間は適当か, 質問数は適当か, またこの質問票に回答しても良いと思うか)， 文章のわかりやすさ（説明文抒よび質問項目）, (2) 説明文（説明文はわかりやすいか)，(3) 質問 項目（質問文は簡単に理解できたか，質問内容 はどのような意味だと理解したか，質問内容は 回答しづらいか), (4) 回答肢（回答肢はわかり やすく，質問に対応しているか）について参加 者に意見を求めた。

\section{3. パイロット調查後のレビューと翻訳終了}

(Fig.1 : 手順 8)

パイロット調查の結果について, 上記の手順 1〜6に携わった日本語を母国語とする 3 名が レビューとともに暫定日本語版に対する微修正 を実施し，言語的妥当性が担保された日本語版 PDI が完成した (手順 8)。

\section{結果}

完成した原作版と日本語版の比較を Table 1 に示した。

\section{1. 日本語暫定版までの作成過程}

\section{(1) 質問票の名称}

まず，名称の Pain Disability Index について， Disability という単語そのものには「生活」とい う意味はないが，質問票のコンセプトが日常生 活全般にわたる行動や活動が痛みによってどの くらい妨げられているかを定量することであり， 最近の疼痛医療の文脈で「disability due to pain」と英語で表現される際には，日本語の 「痛みによる (日常) 生活障害」と翻訳される傾 向にある。さらに，現在普及している質問票で あるPDAS も「疼痛生活障害」という日本語名 を名称に使用し, Pain Disability と英訳してい る。それらを踏まえて, 「疼痛生活障害指標」と 訳した。上述した “sexual behavior”と“lifesupport activity”の 2 項目を削除した 5 項目版 については，7 項目からなるフルバージョンと 区別するために「疼痛生活障害指標（5 項目 版)」という名称にした。英語表記の場合はそ れぞれ, Japanese version of Pain Disability Index（PDI-J）および Japanese version of Pain Disability Index -5 items (PDI-5-J) とする。こ れらに関しては特に翻訳過程で異論はなかった。 
Table 1 疼痛障害指標の英語版と日本語版の比較

Comparison of the English and Japanese versions of the Pain Disability Index

名称

Pain Disability Index
疼痛生活障害指標：PDI-J

疼痛生活障害指標 (5 項目版) : PDI-5-J

\section{説明文}

The rating scales below measure the impact of chronic pain in your everyday life. We want to know how much your pain is preventing you from doing your normal activities.

以下の質問は, 痛みによって, 日常生活のどのような行動や活 動が, どのくらいさまたげられているかを調べるためのもの です。

For each of the 7 categories of life activity listed, circle the one number that best reflects the level of disability you typically experience.

A score of 0 means no disability at all. A score of 10 means that all the activities which you would normally do have been disrupted or prevented by your pain.

それぞれの行動や活動について, 最もあてはまる点数を○で かこんでください。

0点は痛みによって行動や活動がまったくさまたげられてい ないことを意味し, 10 点はふだんあなたが行っている行動や 活動が, 痛みのせいで完全に中断される,またはやろうとする ことすらできないことを意味します。

Your rating should reflect the overall impact of pain in your life, not just when the pain is at its worst. Make a rating for every category.

また, 痛みが一番強いときのことだけでなく, 日常生活におけ る痛みの全体的な影響がどのくらいかを答えてください。

If you think a category does not apply to you, circle "0."

(質問している行動や活動がそもそもあなたにあてはまらな

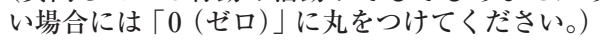

\section{質問項目}

\section{Family/home responsibilities}

This category refers to activities related to the home or family. It includes chores and duties performed around the house (eg, yard work) and errands or favors for other family members (eg, driving the children to school)

\section{Recreation}

This category includes hobbies, sports, and other leisure-time activities.

\section{Social activity}

This category includes parties, theater, concerts, dining out, and other social activities that are attended with family and friends.

\begin{tabular}{l} 
Occupation \\
This category refers to activities that are directly related to one's job. \\
This includes nonpaying jobs as well, such as that of a homemaker or \\
volunteer worker. \\
\hline Sexual behavior \\
This category refers to the frequency and quality of one's sex life. \\
Self-care \\
This category includes personal maintenance and independent daily \\
living activities (eg, taking a shower, driving, getting dressed)
\end{tabular}

\section{Life-support activity}

This category refers to basic life-supporting behaviors such as eating, sleeping, and breathing.

\section{家族／家庭での役割}

この質問では, 家庭での活動についておたずねします。家事や 家でやらなければならない仕事（庭の手入れなど）や,家族の ための用事やたのまれごと（子どもを学校に送るなど）のよ うなことが,この質問に含まれます。

\section{楽しみのための活動}

この質問では, 趣味, スポーツ,およびその他の空き時間に楽 しむためにする活動についておたずねします。

\section{社会的活動}

この質問では,家族以外の友人や知り合いといっしょに参加 する活動についておたずねします。パーティーや映画館, コ ンサートにいくこと, 外食すること, その他の社交的なこと が,この質問に含まれます。

\section{仕事}

この質問では, 仕事に直接関連する活動についておたずねし ます。この質問には給与が支払われない主婦/主夫やボラン ティアとしての仕事も含まれます。

\section{性生活 $\rightarrow 5$ 項目版では本項目を削除}

この質問では, 性生活の頻度や質についておたずねします。

自分の身の回りのこと（セルフケア）

この質問では, 自分の身の回りのことや日常生活 (シャワー を浴びる, 服を着る, 電車・バスにのるなど) を自分でするこ とについておたずねします。

命を維持するためのこと $\rightarrow 5$ 項目版では本項目を削除

この質問では，食べる，眠る，息をするなどの，生きるため の基本的な行動についておたずねします。

\section{回答肢の番号に添えられた文言}

No disability

Moderate

Total disability
まったくさまたげられていない

中程度さまたげられている

完全にさまたげられている 
（2）全体における disabilityの訳語

全体を通して，本質問票に頻回に使用される $\lceil$ disability」の訳語について述べる。質問票の名 称としては痛みによる「生活障害」という言葉 が日本における痛みの臨床や研究の現場で一般 的に使用されている現状から「障害」という表 現を残したが，逆翻訳者より最近の英語圈の一 般社会においては「disability」「disable」という 言い回しは差別的, 侮荗的意味を含むことから 避けられる傾向にあり，それらは「disability」 よりは婉曲的でな「interfere」「prevent」等に置 き換えられる傾向にあるという意見をうけて， これらの日本語訳として「さまたげられる」を あてた（「妨」は中学卒業レベルの常用漢字であ るが, 訓読み表記の「妨げる」は読みにくいと いう意見から，ひらがな表記を用いることにし た）。

\section{(3) 質問項目の訳語}

説明文の翻訳は質問項目の内容を考慮して文 章内容を調整したという経緯から，先に質問項 目の訳語について述べる。なお, 上述した通り, 質問項目は初版と今回翻訳した改訂版で一貫し た英文が使用されてきた。質問項目については, 筆者らが作成した逆翻訳について，原作版管理 者からの修正意見は唯一, 当初著者らが各項目 の具体事例についての主語である,「This category〜」を省略して「〜のような活動がこ こに含まれます」と訳していたところ，逆翻訳 された内容について主語は「This category〜」 とするようにとの指摘であった。日本語では主 語が省略されていても意味は通じるが，より明 確にするために各項目の具体事例はすべて「こ の質問では，〜についておたずねします」とい う表現に統一し，この修正した文章を再度逆翻 訳した内容を原作責任者に提示して承諾を得た。

\section{a) Family/home responsibilities : \\ 家族/家庭での役割}

$\lceil$ responsibility」には責任の意味があり，「家 族/家庭における責任」という順翻訳案も出たが, 日本語で家族/家庭における責任というと精神 論的な意味合いも含まれ，この後に続く具体的 事例から判断しても，もう少しカジュアルな日 常的な作業のことを指すと考えた。しかしなが ら，気が向かなければやらなくてもいいような 事柄ではなく, “It includes chores and duties” とあるように，義務的な意味合いを含むことか ら，「役割」と訳した。また，役割には漢字が読 みやすいようルビをつけることにした。

具体的事例のうち, “yard work（庭の手入 れ)”について, 日本では庭がない家屋も多く, 米国ほど「庭の手入れ」は一般的な家庭内の作 業ではないのではないかという意見があったが, 意味はわかることからこのままにした。 “driving the children to school” は直訳すると 「子どもたちを学校まで車で連れて行く」とな るが, 日本では保護者による児童の送り迎えは 徒歩や自転車, 公共交通機関の使用が一般的で, 特に居住地ごとに校区が定められた公立校に自 家用車で送迎することは特別な事情がない限り 習慣的ではないことから，自動車という手段に ついては省略し，この部分は「子どもを学校に 送る」と訳した。

\section{b) Recreation : 楽しみのための活動}

“recreation”については, 外来語としてカ夕 カナで「レクリエーション」があてられるが, 高齢者には難しいのではないか, あるいは反対 に昭和時代には「レクリエーション」という語 は多用されたが最近使われない傾向にあり，若 者にとってかえって難解ではないかという意見 が出た。そこで, 具体事例の hobbies (趣味), sports (スポーツ), and other leisure-time ac- 
tivities（および，その他の空き時間に楽しむた めにする活動)”も踏まえて,「楽しみのための 活動」と訳した。

c) Social activity : 社会的活動

“social activity”は「社会的活動」という翻訳 が訳者全員で一致したが，日本語で「社会的活 動」という単語を聞いただけでは，具体的にど のような活動を指すのかわからないという意見 が出た。しかしながら，このあとに続く具体的 事例「"that are attended with family and friends (家族以外の友人や知り合いといっしょ に参加する活動)”かっ, “parties, theater, concerts, dining out, and other social activities (パーティーや映画館，コンサートにいくこと， 外食すること，その他の社交的なこと)”が平 易でわかりやすいため，何について問われてい るのかはわかるのではないかという判断で, 項 目名としては「社会的活動」とした。

d) Occupation : 仕事

“occupation”は「仕事」と訳した。「a homemaker」の訳については, ジェンダーバランス を考慮して「主婦/主夫」と翻訳することにし た。

e) Sexual behavior : 性生活

“sexual behavior” は「性生活」という翻訳が 訳者全員で一致した。補助的な説明文である "This category refers to the frequency and quality of one’s sex life.”の訳についても特に当 該翻訳グループ内での異論はなく，「この質問 では，性生活の頻度や質についておたずねしま す。」とした。

性生活に関してはプライベートかつ繊細な質 問で，日本文化においては特に実施が難しい項 目であることが予測される。著者らが欧米の研 究者から聴取した内容によると, 欧米文化でも 同様のようで，回答率も低いことから当該項目
は 5 項目版では使用されていない。

f） Self-care：自分の身の回りのこと (セルフケア)

“self-care”の翻訳については順翻訳の調整 (手順 3）の際に協議に時間がかけられた。 “recreation”と同様に, “self-care”についても 外来語としてカタカナ表記の「セルフケア」が 可能で，若い世代には通じるが，高齢者にとっ ては難しいだろうという意見が出た。続く具体 的事例の内容を踏まえて「自分の身の回りのこ と」という訳が考えられたが，あまりに抽象的 なのでセルフケアを添えて「自分の身の回りの こと(セルフケア)」とカタカナ表記を併記す ることにした。

また，具体的事例の “eg, taking a shower, driving, getting dressed” の部分について，日本 ではシャワーよりも湯船に浸かるほうが一般的 だという意見もあったが，痛みの強い患者の場 合は湯船に浸かる動きがシャワーより困難な傾 向にあるという意見から，そのまま「シャワー を浴びる」と訳した。また，日本では米国と比 較して，移動に関しては自動車の運転 “driving” よりも公共交通機関の利用のほうが敷居は低い であろうという意見から，「電車・バスにのる」 と訳すことにした。

g） Life-support activity：命を維持するた めのこと

本項目の “life-support activity” の翻訳につい ても順翻訳の調整（手順 3) の際に時間がかけら れた。具体事例として挙げられた “This category refers to basic life-supporting behaviors such as eating, sleeping, and breathing. (「この質問では, 食べる，眠る，息をするなどの，生きるための 基本的な行動についておたずねします」と翻訳 した。)”読めば，この項目で何を問われてい るのかはわかるが，これらを統括する翻訳は困 
難であった。協議の結果，「命を維持するため のこと」と翻訳することとし，「維持」は難解な 部類の漢字に相当するため, 読みやすいように ルビをつけることにした。なお，上述したよう に当該項目は，5項目版では使用されていない。 （4）説明文の訳語

「activities」の訳語については，1語で「活 動」とだけ訳すと, 質問項目の「性生活」「自分 の身の回りのこと」「命を維持するためのこと」 は日本語の「活動」とは言えないのではないか という意見から，「行動や活動」と 2 語で訳す ことにした。

原作版説明文 3 文目の “For each of the 7 categories of life activity listed,” は直訳すると「以 下に並べられた 7 種類の life activity」となるが, $\lceil 7$ 種類」と項目数を記載すると 7 項目版と 5 項 目版でこの部分を $「 7$ 種類」と「5 種類」と 2 種 類に使い分ける必要が出てきて誤りの元である ため, 7 項目版と 5 項目版で同じ説明文が使用 できるように，この部分の項目数については省 略した。

説明文中程の “A score of 0 means no disability at all.”については, パイロット調查の後に表 現を修正したため, パイロット調查の結果とし て後述する。

最後の一文 “If you think a category does not apply to you, circle '0'” の中にある, “circle '0” について，軽微な点ではあるが，“0’がローマ 数字の 0 であるか, アルファベット小文字の 0 であるか混乱しないように，0の隣に（ゼロ） を添えた。またこの最後の一文は補足的な内容 であるため，日本語版ではカッコ（ ）をつける ことにした。

（5）回答肢の作成と回答肢の番号に添えられた 文言の訳語

回答肢には原作版と同様に 0 から 10 までの
番号を列記して丸をつける方式としたが，原作 版より数字の視認性が良いように工夫した。ま た，回答肢の番号に添えられた文言について， 逆翻訳までは初版と同様の「No disability (まったくさまたげられていない)」「Total disability(完全にさまたげられている)」の 2 項目 としていたが，原作管理者より真ん中の 「Moderate」も添えたほうが良いというコメン トがあり，「Moderate」を訳した「中程度さま たげられている」も追加した。

以上までの手順で暫定日本語版 PDI を作成 した。

\section{2. パイロット調查と調查終了後のレビュー}

痛みのある患者 5 名に実施したパイロット調 查の結果, 回答に要した時間は平均 125.2 秒 （標準偏差 28.4）で，回答に要した時間につい ての患者自身の主観的評価は 5 名中 4 名が時間 は適当であったと回答し，1名がどちらでもな いと回答した。

全体的なわかりやすさについては，概放良好 な回答ではあるが，質問意図がわかりにくいと 回答した者が 1 名であった。質問数は 4 名が適 当であると回答し，1名については問われる項 目が少ない気がすると回答した。また, 5 名とも またこの質問票に回答しても良いと回答した。

説明文の理解しやすさについては概ね良好で あるとの回答であったが，説明文が同様の内容 の繰り返しになっているように感じるという答 えたものが 1 名いた。

質問項目の理解しやすさや意味についても概 ね良好であるとの回答が得られたが，最後の質 問項目がわかりづらいとの意見や，家族/家庭 の役割が複数ある場合に(こなせている役割と こなせていない役割があるため) それらを区別 して答えられない点がわかりづらいとの意見が 


\section{疼痛生活障害指標}

以下の質問は、痛みによって、日常生活のどのような行動也活動が、どのくらいさまたげられ ているかを調べるためのものです。それそれの行動や活動について、最もあてはまる点数を○で かこんでください。

○点は痛みによって行動也活動がまったくさまたげられていないことを意味し、10点はふだ んあなたが行っている行動や活動が、痛みのせいで完全に中断される、またはやろうとすること すらできないことを意味します。

また、痛みが一番強いときのことだけでなく、日常生活における痛みの全体的な影響がどのく らいかを答えてください。

（質問している行動や活動がそもそもあなたにあてはまらない場合には「○（ゼロ）にに丸をつ けてください。)

\section{家族/家庭での役割}

この質問では、家庭での活動についておたずねします。 家事嫁でやらなければならない仕事（庭の手入れな ど）や、家族のための用事やたのま㞦と（子どもを 学校に送るなど）のようなことが、この質問に含まれ ます。

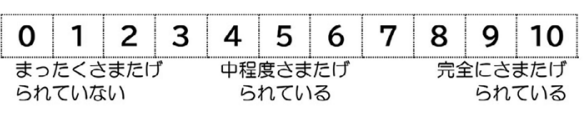

\section{楽しみのための活動}

この質問では、趣味、スポーツ、およびその他の空き 時間に楽しむためにする活動についておたずねします。

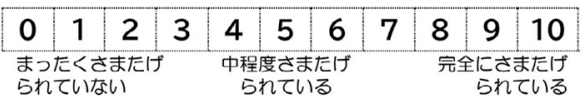

\section{社会的活動}

この質問では、家族以外の友人や知り合いといっしょに 参加する活動についておたずねします。パーティーや映 画館、コンサートにいくこと、外食すること、その他の

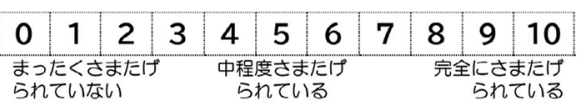
社交的なことが、この質問に含まれます。

\section{仕事}

この質問では、仕事に直接関連する活動についておたず ねします。この質問には給与が支払われない主婦／主夫 やボランティアとしての仕事も含まれます。

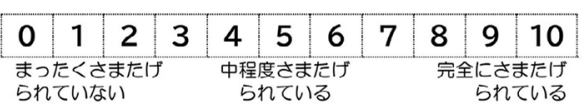

\section{性生活}

この質問では、性生活の頻度や質についておたすねね

します。

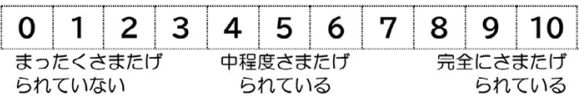

自分の身の回りのこと(セルフケア)

この質問では、自分の身の回りのことや日常生活（シャ ワーを浴びる、服を着る、電車・バスにのるなど）を 自分ですることについておたずねします。

\begin{tabular}{|c|c|c|c|c|c|c|c|c|c|c|}
\hline 0 & 1 & 2 & 3 & 4 & 5 & 6 & 7 & \multicolumn{2}{|c|}{$\begin{array}{l}3 \quad 9 \\
\end{array}$} & 10 \\
\hline \multicolumn{4}{|c|}{$\begin{array}{l}\text { つたくさままたは } \\
\text { れていない }\end{array}$} & & $n$ & & & & & $\begin{array}{l}\text { Eたげ } \\
\text { ¿いる }\end{array}$ \\
\hline
\end{tabular}

\section{命を維持するためのこと}

この質問では、食べる、眠る、息をするなどの、生きる ための基本的な行動についておたずねします。

\begin{tabular}{|c|c|c|c|c|c|c|c|c|c|c|}
\hline 0 & 1 & 2 & 3 & 4 & 5 & 6 & 7 & 8 & 9 & 10 \\
\hline $\begin{array}{l}\text { Fっ } \\
5 れ 2\end{array}$ & $\begin{array}{l}\text { E< } \\
\text { てい/ }\end{array}$ & & & & $\begin{array}{l}\text { 度さま } \\
\text { れてい }\end{array}$ & & & & $\begin{array}{l}\text { Ed } \\
5 \pi\end{array}$ & $\begin{array}{l}\text { またけ } \\
\text { ている }\end{array}$ \\
\hline
\end{tabular}

【著者注棌】今回作成した言語的に妥当なPDI日本語翻訳版については、著者らの許可なしに自由な使用が可能 である。ただし、一般的な手続きとしてPDI-JひびPDI-5-Jの一部または全使用に関しては本稿、もしくは今後執 筆予定の計量心理学的な特性に関する論文を引用していただきたい。

Fig.3 日本語版疼痛障害指標

The Japanese version of the Pain Disability Index (PDI-J) 


\section{疼痛生活障害指標(5項目版)}

以下の質問は、痛みによって、日常生活のどのような行動や活動が、どのくらいさまたげられ ているかを調べるためのものです。それそれの行動や活動について、最もあてはまる点数を○で かこんでください。

○点は痛みによって行動也活動がまったくさまたげられていないことを意味し、10点はらだ んあなたが行っている行動や活動が、痛みのせいで完全に中断される、またはやろうとすること すらできないことを意味します。

また、痛みが一番強いときのことだけでなく、日常生活における痛みの全体的な影響が

どのくらいかを答えてください。

(質問している行動也活動がそもそもあなたにあてはまらない場合には「○(ゼロ)」に丸を つけてください。)

\section{家族/家庭での役割}

この質問では、家庭での活動についておたずねします。 家事や家でやらなければならない仕事（庭の手入れな ど）、家族のための用事やたのまれごと（子どもを

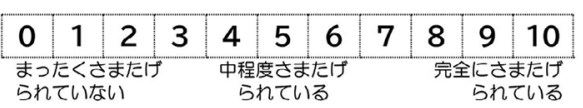
学校に送るなど) のようなことが、この質問に含まれ ます。

\section{楽しみのための活動}

この質問では、趣味、スポーツ、およびその他の空き 時間に楽しむためにする活動についておたずねします。

\begin{tabular}{|c|c|c|c|c|c|c|c|c|c|c|}
\hline 0 & 1 & 2 & 3 & 4 & 5 & 6 & 7 & 8 & 9 & 10 \\
\hline & $t \in<0$ & $\begin{array}{l}\text { ¿またに } \\
\vdots い\end{array}$ & & $\begin{array}{c}\text { 中程 } \\
5\end{array}$ & & & & & $\begin{array}{l}\text { 全にd } \\
5 れ\end{array}$ & $\begin{array}{l}\text { まEけ } \\
\text { ている }\end{array}$ \\
\hline
\end{tabular}

\section{社会的活動}

この質問では、家族以外の友人や知り合いといっしょに 参加する活動についておたずねします。パーティーや映 画館、コンサートにいくこと、外食すること、その他の

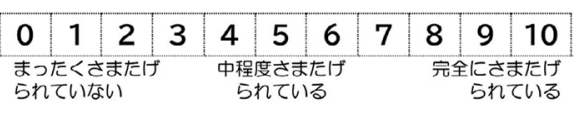
社交的なことが、この質問に含まれます。

\section{仕事}

この質問では、仕事に直接関連する活動について おたずねします。この質問には給与が支払われない 主婦／主夫切ランティアとしての仕事も含まれます。

\begin{tabular}{|c|c|c|c|c|c|c|c|c|c|c|}
\hline 0 & 1 & 2 & 3 & 4 & 5 & 6 & 7 & 8 & 9 & 10 \\
\hline $\begin{array}{l}\text { まっ } \\
5 れ\end{array}$ & $\begin{array}{l}\text { Eくく } \\
\text { ていた }\end{array}$ & $\begin{array}{l}ま た । \\
\vdots\end{array}$ & & 中程 & 度ざ & & & & $5 れ$ & $\begin{array}{l}\text { またげ } \\
\text { こいる }\end{array}$ \\
\hline
\end{tabular}

\section{自分の身の回りのこと(セルフケア)}

この質問では、自分の身の回りのことや曰常生活 (シャワーを浴びる、服を着る、電車・バスにのる など)を自分でることについておたずねします。

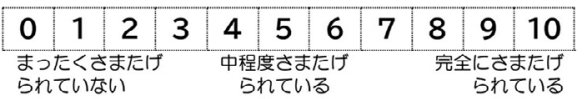

【著者注釈】今回作成した言語的に妥当なPDI日本語翻訳版については、著者らの許可なしに自由な使用が可能 である。ただし、一般的な手続きとしてPDI-J及びPDI-5-Jの一部または全使用に関しては本稿、もしくは今後執 筆予定の計量心理学的な特性に関する論文を引用していただきたい。

Fig.4 日本語版疼痛障害指標 (5 項目版)

The Japanese version of the 5-item Pain Disability Index (PDI-5-J) 
あった。また，個別具体的な行動を細かく問わ れているわけではないことから，質問項目の具 体性が足りないことについての指摘が 2 名から あった。一方で，具体性については「抽象的す ぎず，具体的すぎず普通な感じ。」というポジ ティブなコメントも 1 名から寄せられた。

その他著者らが懸念していた性生活の項目に ついては，「性生活に関する項目はどう答えた ら良いかわからなかった」というやや困惑した コメントがみられた一方，「性生活に関する質 問があるのは良いと思う」という想定外の肯定 的なコメントも得られた。

パイロット調查後のレビューにおいて，暫定 日本語版に対して以下の一点のみ修正の必要が あると判断した。暫定日本語版の説明文の中で 使用していた「0点は痛みがまったくさまたげ にならないことを意味し」という訳文がおかし いという意見が寄せられたため, パイロット調 查後のレビューによって，この部分は「0 点は 痛みによって行動や活動がまったくさまたげら れていないことを意味し」という訳文に差し替 えた。

以上の手順によって，言語的妥当性が担保さ れた日本語翻訳版 PDI が完成した。完成した PDI-J および PDI-5-J を Fig.3・Fig.4 として示 す。

考 察

日本にPDI 導入すべく，言語的妥当性を 担保した日本語翻訳版を作成した。まず， ISPOR が作成した，言語的に妥当な尺度の翻 訳版を作成する際に標準的に使用される国際的 なガイドラインに準拠し，英語原作版の作成に 携わった管理者と原作の設問意眓等の確認を取 り合いながら，日本文化に精通したトリリンガ
ル話者の参画も得て文化的な調整を行うことで, 将来の国際比較に耐えうる質の高い翻訳を完成 させた。続いて, 疼痛患者を対象としたパイ ロット調査を通じて害際に質問票に回答する日 本の患者にとって，回答しやすい言語表現とな るように努めた。

説明文は初版 PDI と改訂版 PDI（今回翻訳し た原作版）で異なるが，一番大きな違いは，改 訂版では最後の文章の “If you think a category does not apply to you, circle '0'”が付け加えら れている点である。この訳は，「質問している 行動や活動がそもそもあなたにあてはまらない 場合には「0(ゼロ)」に丸をつけてください。」 とした。この一文が含まれないと，質問項目に 回答する際に（痛みに関わらず）そもそも退職 して仕事をしていない場合や，「家族/家庭」に 相当する環境で生活していない場合などについ て，その項目が空欄 (欠損值) となってしまう。 空欄の場合に，記載漏れなのか，該当しないた めに回答しょうがないのかが見分けがつかない ため，評価者が空欄を後から 0 点とするのは評 価として不適当である。そこで，回答しょうが ない場合には，回答者に 0 点と記載してもらい， 記載漏れと区別しょうというのが意図である。 質問項目で問われた内容に対して回答したくな い場合には，この方法では空欄になるのが防げ ない。しかし，このような断りを入れておくこ とで，例えば性生活に関しての質問項目であれ ば，問題がない場合に「0 点」とつける場合に も羞恥心や躊躇が軽減し，回答しやすいのでは ないかと想定される。

説明文の翻訳にあたって, 痛みと回答者の （文法的な）主述関係については特に意識して 原作版 (“how much your pain is preventing you from doing your normal activities “ would normally do have been disrupted or 
Japanese Pain Disability Index

prevented by your pain” の記載部分）に対して 忠実な表現を心掛け，回答者本人を主体として 「痛みによって行動や活動がさまたげられる」 という受け身表現（受動態）にするスタイルに 統一した。痛みによる生活障害の程度を評価す るための質問票の文章表現において，例えば， 「痛みが行動や活動をさまたげる」のように， 文法上の主述関係を移動させると評価が安定し ない可能性があることから，原作版と主述を統 一することが重要であると考えた。

痛みは主観的な体験であることから，患者本 人が自分自身と痛みとの主従関係（文法上の主 述関係ではなく）をどのように捉えているかに ついては，痛みの診療や研究を実施する上で非 常に重要である。Dawson らは痛みが自分の活 動にどの程度影響しているかと患者自身が考え る信念 (belief) のことを “Perception of disability”と命名しており，身体機能的そのものとは 必ずしも一致しないことを述べている ${ }^{9)}$ 。PDI はこの “Perception of disability”を定量する目 的で使用されている7)。

一連の標準的な手続きを経た結果，原作版と 同等の概念を内含し，言語的に妥当な PDI 日 本語翻訳版（PDI-J および PDI-5-J）が完成し た。本質問票については今回の言語的な検討に 続いて, さらに計量心理学的な特性についても 検討する必要がある。現在著者らは計量心理学 的な特性についての検討を実施中である。

なお，原作版管理者の Dr. Taitによると， PDI はパブリックドメイン（知的財産権が発生 していないか消滅している状態)であり，学術 目的商業目的に関わらず，自由に使用して構わ ないとのことである。今回作成した言語的に妥 当な PDI 日本語翻訳版についても，著者らの 許可なしに自由な使用が可能である。

\section{結語}

痛みによる生活障害の簡便な尺度として国際 的に普及している PDIについて，言語的妥当 性を担保した日本語翻訳版 PDIを作成した。 日本においても PDI-J および PDI-5-J が疼痛 治療に扔ける患者評価や臨床研究に広く活用さ れることを期待している。

\section{謝 辞}

PDI の日本語翻訳版作成に多大なご協力をいただ いたDr. Raymond Taitに深謝いたします。ま た，パイロット調查の実施にご協力いただいた医 療法人暁会田辺整形外科田辺暁人理事長，および 研究協力をしてくださった患者のみなさまにも御 礼を申し上げます。

本研究は厚生労働行政推進調查事業：「慢性疼痛 診療システムの均てん化と痛みセンター診療デー タベースの活用による医療向上を目指す研究 (19FG2001)」による一部助成を受けて実施しま した。筆頭著者の山田は日本学術振興会の海外特 別研究員として, 研究活動費の支給をうけていま す。

\section{文 献}

1) Lee, T.H., Zero Pain Is Not the Goal, JAMA, 315 (2016) 1575-1577.

2) Yamashiro, K., Arimura, T., Iwaki, R., Jensen, M.P., Kubo, C., Hosoi, M., A multidimensional measure of pain interference: reliability and validity of the pain disability assessment scale, Clin. J. Pain, 27 (2011) 338-343.

3) Pollard, C., Preliminary validity study of the pain disability index, Percept. Mot. Ski., 59 (1984) 974.

4) Chibnall, J.T., Tait, R.C., The Pain Disability Index: factor structure and normative data, Arch. Phys. Med. Rehabil., 75 (1994) 10821086.

5) Wild, D., Grove, A., Martin, M., Eremenco, S., McElroy, S., Verjee-Lorenz, A., Erikson, P., ISPOR Task Force for Translation and Cultural Adaptation, Principles of Good Practice for the Translation and Cultural Adaptation Process for Patient-Reported Outcomes (PRO) Measures: report of the ISPOR Task Force for Translation and Cultural Adaptation, Value Health, 8 (2005) 94-104. 
6）稲田尚子, 尺度翻訳に関する基本指針, 行動療 法研究, 41 (2015) 117-125.

7) Sullivan, M.J., PGAP Treatment Manual 4th Edition, Halifax: PDP Program Inc., 2014.

8) 松平浩, 犬塚恭子, 菊池徳昌, 寒河江千鶴, 有阪 真由美, 磯村達也, Robert P. Miller, 日本語版 TampaScaleforKinesiophobia (TSK-J) の開発: 言語的妥当性を担保した翻訳版の作成. 臨整 外, 48 (2013) 13-19.
9) Dawson, R., Sellers, D.E., Spross, J.A., Jablonski, E.S., Hoyer, D.R., Solomon, M.Z., Do patients' beliefs act as barriers to effective pain management behaviors and outcomes in patients with cancer-related or noncancer-related pain?, Oncol. Nurs. Forum, 32 (2005) 363-374.

Address for correspondence: Keiko Yamada Department of Anesthesiology and Pain Medicine, Juntendo University Faculty of Medicine 2-1-1 Hongo, Bunkyo-ku, Tokyo 113-0033, Japan 